REVISTA DE DERECHO UNED, núm. 4, 2009

\title{
LAS INSTITUCIONES POLÍTICAS DE LA DEMOCRACIA ATENIENSE
}

\author{
HÉctor Álvarez García \\ Doctorando (UNED) (FPU-MICINN) ${ }^{1}$
}

Resumen: La democracia no surgió espontáneamente en Atenas, sino que fue el fruto de un arduo proceso de conquistas sociales, económicas y políticas, alcanzadas gracias a las revoluciones del demos que, oprimido secularmente por los eupátridas, se levantó contra el régimen político impuesto por la religión primitiva del Ática. Gracias a las reformas de Solón y de Clístenes, accedió a los primeros derechos políticos, comenzando el camino por el que tendría que transitar hasta obtener el poder político que tradicionalmente habían monopolizado los eupátridas.

Con la ascensión política de Pericles al cargo de strategos y sus reformas, la democracia se instituye como la forma de gobierno de la polis, que se prolongará hasta el 322 a.C., año en el que los macedonios vencieron a Atenas.

El sistema político de la democracia directa, durante los ciento cincuenta años de vigencia en la ciudad, se sustentó sobre la base de tres instituciones político-participativas: la Ekklesia, la Boulé, y los Dikasterios, en las que podían intervenir todos los ciudadanos, de modo que los poderes soberanos eran ejercidos directamente y sin representantes; en sus manos estaba el destino y el futuro de Atenas. Por tanto, el objeto central de este artículo es estudiar su composición, competencias, funcionamiento, etc.

Palabras clave: democracia, participación, ciudadano e igualdad.

Abstract: The democracy was not restored spontaneously in Athens, but that was the fruit of an arduous process of social, economic con- 
quests and political reached thanks to the revolutions of we give that, pressed secularly by the eupatridas ones, it rose against the political regime imposed by the primitive religion of the Atica. Thanks to the reforms of Solon and Clistenes, were able to accede to the first political rights, beginning the way by which it would have to journey until obtaining the political power that traditionally they had monopolized the eupatridas ones.

With the political ascent of Pericles to the position of strategos and its reforms, the democracy is instituted as form of government of polis, whose use will extend until the Macedonians won to Athens in 322 year B.C.

The political system of the direct democracy, during the one hundred fifty years of use in Athens, was sustained on the base of three institutions political-participativas: the Ekklesia, the Boule, and the Dikasterios, in which all the citizens, so that the town directly exerted and without representatives all the sovereign powers, in their hand could take part actively was the destiny of polis. Therefore, the central object of this article is to study its competitions, composition, operation, etc.

Key words: democracy, participation, citizen and equality.

Sumario: I. Introducción.-II. La evolución política de Atenas hasta la democracia.-II.1. La monarquía.-II.2. La aristocracia.-II.3. La timocracia.-II.4. La reforma democrática de Clístenes.-III. La democracia ateninese.-III.1. Las instituciones políticas.-III.1.A. La boulé.-III.1.B. La ekklesia.-III.1.C. Los dikasterios.-IV. Conclusiones.

\section{INTRODUCCIÓN}

La técnica de la política es una virtud innata en el ser humano que adicionada al sentido común, justicia e integridad moral, presentes en la naturaleza de todos los hombres, nos permite concluir que todos tenemos una capacidad natural de entender y comprender los asuntos públicos y de tomar aquellas decisiones que van a proporcionar un mayor beneficio para la comunidad. Según PROTÁGORAS, el conocimiento de la política es un talento natural que no se encuentra con la misma intensidad en todas las personas, sino que difiere de unos a otros al igual que ocurre con el resto de los saberes. Sin embargo, en este estado natural no es más que una potencialidad que necesita de un estímulo externo: la educación, para que se materiali- 
ce y pueda ser aplicado. Ahora bien, es la calidad de este impulso la que determinará el grado de destreza que cada persona alcance en el arte de la política.

Esta facultad natural se cultiva y desarrolla óptimamente en el régimen político de la democracia participativa, porque permite al ciudadano formarse mediante su participación en la asamblea, en el gobierno, desempeñando los cargos públicos más diversos y participando como jurado en los tribunales populares. En definitiva, ejerciendo directamente los poderes soberanos, sin ningún tipo de representantes que distorsionen, alteren o manipulen la voluntad del pueblo para adaptarla, según su conveniencia, a sus intereses privados, posibilitando que todos los ciudadanos tengan al menos una pericia aceptable en política.

La democracia no surgió espontáneamente en Atenas, sino que fue el resultado de un largo proceso de conquistas sociales, económicas y políticas, conseguidas gracias a las revoluciones del pueblo, que subyugado y profundamente discriminado durante siglos por la poderosa aristocracia (eupátridas), se levantó contra el régimen político revelado, auspiciado y sustentado por la religión tradicional del Ática. Gracias a las reformas solonianas, consiguió acceder a la propiedad y a los primeros derechos políticos, comenzándose a iluminar la senda por la que tendría que caminar hasta alcanzar el poder político que tradicionalmente habían monopolizado los eupátridas.

Clístenes continuará el camino iniciado hacia la democracia otorgando nuevos derechos políticos al pueblo y diseñando una organización político-territorial: la división de Atenas en diez tribus, con la que asestó el golpe definitivo al poder político-religioso de los eupátridas, al eliminar todos los privilegios basados en el nacimiento de los que secularmente habían disfrutado, y suprimir la influencia de la primitiva religión en la vida política ateniense instaurando nuevos cultos a divinidades diferentes.

Con la ascensión de Pericles al cargo de strategos y sus reformas políticas, entraremos en el período conocido como «democracia radical», llamado así porque se consiguió la isonomía entre ciudadanos; la totalidad del poder político se le entregó al puebloํㅜ, canalizándose,

${ }_{1}$ «La libertad de los antiguos consistía en ejercer de forma colectiva pero directa, distintos aspectos del conjunto de la soberanía en deliberar en la plaza pública sobre la guerra y la paz, en concluir alianzas con los extranjeros, en votar las leyes, en pronunciar sentencias, en examinar las cuentas, los actos, la gestión de los magistrados, 
sobre la base de una incipiente división de poderes, en diversas instituciones políticas participativas que perdurarán en el tiempo hasta que en el año 322 a.C., el ejército macedonio de Antípatro y Cratero venció a Atenas en la batalla de Cranón. Podemos afirmar que es la primera y más pura experiencia democrática de la humanidad.

\section{LA EVOLUCIÓN POLÍTICA DE ATENAS HASTA LA DEMOCRACIA}

\section{II.1. La monarquía}

En la época primitiva, Grecia estaba ocupada por familias ${ }^{2}$, formadas por línea principal, ramas secundarias y clientes³ ${ }^{3}$ en el Ática

en hacerles comparecer ante todo el pueblo, acusarles, condenarles o absolverles; pero a la vez que los antiguos llamaban libertad a todo esto, admitían como compatible con esta libertad colectiva la completa sumisión del individuo a la autoridad del conjunto» (CONSTANT, B., "De la libertad de los antiguos comparada con la libertad de los modernos», Escritos políticos, Estudio preliminar, traducción y notas de María Luisa Sánchez Mejía, Madrid, 1997, p. 260). Cfr. ROUSSEAU, J.J., Du contrat social ou principes du droit politique, Chapitre IV et XV du Livre III.

${ }^{2}$ Las creencias arcaicas de los griegos se basaban en el culto a los antepasados, que tenían la consideración de dioses, y les obligaban a realizar múltiples ritos, ceremonias y sacrificios para honrar a sus muertos. Era una religión puramente doméstica donde cada familia (gens), entendida como asociación religiosa, antes que como unión natural basada en el amor y en el afecto, se reunía alrededor del hogar (el lugar de la casa donde se prendía el fuego sagrado, elevado al rango de divinidad, que tenía que estar siempre encendido y había que ofrecerle libaciones y ofrendas para que proporcionara prosperidad a la familia). Cada gens tenía su propia religión porque adoraba a sus propios dioses y establecía sus propias ceremonias, plegarias, oraciones y ritos para realizar el culto a sus muertos. Era una religión muy celosa de su propio culto, los antepasados sólo podían ser venerados por los miembros de su propia familia; se repudiaba cualquier mínima relación con otras gens — dos casas nunca podían tocarse, ni podían enterrarse personas de diferentes familias en la misma tumba, ningún extraño podía acercarse cuando se estaban practicando el culto, ni conocer las oraciones, los ritos o ceremonias que una familia realizaba, ni tocar la tumba de los antepasados-, lo que provocó el aislamiento de las familias. Junto a esta idea religiosa, que halló la divinidad en el propio hombre, en aquello que su conciencia le decía que había de sagrado en el ser humano: el alma; se desarrolló también un sentimiento religioso cuya idea de lo divino se residenció en la naturaleza física que constantemente percibía: el sol, la noche, la tormenta, lluvia, el huracán, su vida dependía de los agentes físicos, pensaba que tenían voluntad y libertad de actuación porque en unas ocasiones sufría su ira y en otras se beneficiaba de su bondad, y para granjearse sus favores decidió adorarlos y convertirlos en dioses.

${ }^{3}$ Las creencias del hombre engendraron la moral, las instituciones domésticas (matrimonio, adopción, divorcio, emancipación) y el derecho privado, que no era una creación de la inteligencia humana sino una revelación de los dioses a los hombres, seencargaba de regular las relaciones jurídicas de la gens, basadas en la primogenitura 
se establecieron en cantones independientes ${ }^{4}$ un centenar de pequeñas sociedades, entre las que no fraguó ningún tipo de relación política ni religiosa, sin embargo, los enfrentamientos eran frecuentes entre ellas ${ }^{5}$. Vivían en un régimen de autarquía, gobernadas por los primogénitos, que eran los jefes de las familias y ostentaban el poder político y religioso ${ }^{6}$.

Con el paso del tiempo, la capacidad cognitiva del hombre fue desarrollándose y se ampliaron sus creencias, que tradicionalmente habían quedado circunscritas al culto doméstico, de modo que las familias griegas empezaron a venerar a otras divinidades superiores (héroes comunes), uniéndose con otras gens, formando fratrías. ${ }^{7}$ Esto supuso una apertura que puso fin al aislacionismo en el que habían estado inmersas; cada fratría tenía su jefe: el fratriarca ${ }^{8}$, cuya misión era dirigir los sacrificios y las ceremonias religiosas para honrar a los dioses, asimismo, se encargaba de tomar decisiones políticas sobre aquellos asuntos comunes que afectaban a los intereses de todas las

en la sucesión de la jefatura de la familia y en la perpetuación de la unidad e indivisibilidad de la misma, como medio de garantizar el culto a los muertos. Para este fin la propiedad era inalienable, no era concebida como un derecho subjetivo, sino que la titularidad la ostentaba la familia, y la sucesión se defería siempre en beneficio del primer hijo varón, porque se estaba en la creencia de que el poder reproductor residía exclusivamente en el género masculino y que había sido engendrado para asegurar el culto de los antepasados y los demás habían nacido por amor, de modo que no se procedía a un reparto del caudal relicto entre los hijos. Sin embargo, el primogénito no ostentaba sobre el patrimonio familiar el título de dominus, sino que la figura jurídica que más se aproxima es la de mandatario, disfrutando de plenas facultades para la gestión de todos los bienes de la gens, pero estaba obligado a su conservación para asegurar el culto a sus antepasados que estaban allí enterrados, y a dirigir las ceremonias religiosas, los sacrificios y demás actos religiosos. Los hijos segundones quedaban bajo su protección, frecuentemente eran adoptados por otras familias sin hijos, o se les enviaba a alguna colonia. Las hijas salían de su gens para incorporarse a otra a través del matrimonio, de tal forma que abandonaban su religión doméstica para incorporarse a la de la familia de su marido. También formaban parte de ella los clientes, que eran servidores o esclavos encargados de trabajar las heredades y gozaban de la plena protección del jefe de la gens, se integraban en el culto doméstico por medio de una ceremonia y, desde ese momento, ya podían participar en todos los actos religiosos. A partir de su incorporación solemne a la familia perdían toda su libertad ad infinitum, y tanto ellos como sus descendientes estaban sometidos a la autoridad del jefe de la familia.

${ }^{4}$ PLUTARCO, Teseo, 24.

${ }^{5}$ Ibidem, 13.

${ }^{6}$ La gens celebraba sus asambleas, redactaba sus decretos, que eran obedecidos por sus miembros. TITO LIVIO, VI, 20, SUETONIO, Tiberio, I.

${ }^{7}$ HOMERO considera que es una institución que se extendió por toda Grecia, Ilíada, II, 362. Cfr. DEMÓSTENES, In Macartatum, 14.

${ }^{8}$ DEMÓSTENES, In Eubul, 23. 
gens de la fratria; al igual que las familias, contaban con una asamblea donde resolvían aquellas cuestiones de interés general que les afectaban. ${ }^{9}$

En el Ática, las nuevas creencias religiosas comunes que se despertaron en las conciencias, y también ciertas necesidades llevaron a establecerse vínculos y relaciones entre las innumerables familias, de suerte que se inició un progresivo proceso de constitución de doce fratrias, que culminará hacia el siglo XVI a.C. Varios siglos después, en tiempos de Ión $^{10}$, las fratrias se organizaron en cuatro tribus ${ }^{11}$ al frente de cada una de ellas estaba un filobasileus, con poderes análogos a los que tenían los fratriarcas; asimismo, cada tribu adoraba a sus dioses y celebraba sus asambleas para resolver las cuestiones comunes que afectaban a las tres fratrias que la formaban.

Con el paso del tiempo, Atenas experimentó un notable crecimiento y relevancia sobre las demás fratrias; el rey ateniense Teseo unificó territorial y políticamente el Ática en Atenas. ${ }^{12}$ Fue el fundador de la ciudad de Atenas e instaló el altar, que era el lugar donde se encontraba el fuego sagrado, en el pritaneo; ${ }^{13}$ era el encargado de realizar todas las ceremonias religiosas para honrar a los dioses de la

${ }^{9}$ Sobre el procedimiento para la formación de la voluntad de la asamblea de la fratria, cfr. DEMÓSTENES, In Macartum, 82.

${ }^{10}$ Según la tradición, Ión, nieto de Erecteo rey de Atenas (1397-1347 a. C.), acudió en ayuda de su abuelo cuando los atenienses entraron en guerra con los tracios y los eleusinos (cfr. HERODOTO, 8, 44, 2; TUCÍDIDES, II, 15; PAUSANIAS, 7,5, I; ESTRABÓN, I, 31). Las tribus reciben el nombre de los cuatro hijos de Ión: Egicoreos, Argadeos, Geléontes y Hopletes, cfr. HERODOTO, 5, 66, 2.

${ }^{11}$ Cfr. PÓLUX, VIII, 109-111. Todas las ciudades griegas estaban formadas por tres o cuatro tribus; Ilíada, II, 362 y 668; Odisea, XIX, 177; HERODOTO, IV, 161.

${ }^{12}$ FUSTEL DE COULANGES considera que «Teseo quiso que el pritaneo de Atenas fuese el centro religioso de todo el Ática. Desde entonces quedó fundada la unidad ateniense; religiosamente cada cantón conservó su antiguo culto, pero todos aceptaban un culto común; políticamente, cada cual conservó sus jefes, sus jueces, su derecho a reunirse en asamblea, pero por encima de estos gobiernos locales estuvo el gobierno central de la ciudad». (La ciudad antigua, edición de J.K.Yvars Iberia, Barcelona, 1971, p. 147.) Por el contrario, TUCÍDIDES considera que Teseo destruyó los pritaneos locales, acabó con las magistraturas y las asambleas de las fratrias con el fin de imponer unas instituciones políticas comunes para todo el Ática, (Historia de la Guerra del Peloponeso, II, 15,2). Sin embargo, lo más probable es que fuera sólo un intento, porque mucho tiempo después se encuentran referencias a los cultos locales, las asambleas y a los filobasileus de las tribus. (PÓLUX, VIII, 111; DEMÓSTENES, In Theocrinen)

13 (TUCÍDIDES, II, 15; PAUSANIAS, I, 18). Era el edificio donde se encontraba el hogar común de las fratrias y en el que se celebran las innumerables ceremonias, ritos y sacrificios en honor de los dioses de Atenas. Todas las ciudades griegas tenían un pritaneo. 
ciudad ${ }^{14}$. La sucesión regia se realizaba por herencia en favor del primogénito al que se le transmitían los poderes político-religiosos. Junto con su condición gran pontífice de la ciudad, el rey de Atenas (basileus) era una autoridad política que presidía la asamblea, ejercía las funciones de juez y jefe del ejército. Estaba rodeado de una poderosa aristocracia (eupátridas: los bien nacidos) formada por los jefes de las familias, los fratriarcas y los filobasileus, todos ellos eran miembros del Consejo del Areópago ${ }^{15}$ que le asesoraba sobre aquellos asuntos públicos comunes a todas las comunidades políticas que formaban parte de la Atenas. Cada uno de éstos era rey, con análogas atribuciones, dentro de su concreta comunidad política que siguió conservando su independencia y su autonomía propia en todos los ámbitos, de modo que al monarca ateniense le estaba vedado ingerir en la vida interna de cada familia, fratria o tribu y sólo tenía poder sobre sus jefes. ${ }^{16}$

La asamblea de Atenas era simplemente un foro de debate para la discusión de los restringidos asuntos públicos sobre los que ciudad, y, por tanto, el rey tenía competencia para adoptar decisiones políticas. Estaba formada por el basileus, que la presidía, los eupátridas y el resto de pueblo ${ }^{17}$. Sólo el rey y la poderosa aristocracia tenían derecho de uso de la palabra y, por tanto, libertad para expresar su opinión sobre las cuestiones que afectaban a la res publica; sin embargo, en tiempos de guerra la opinión del adivino ${ }^{18}$ era decisiva, porque sólo se iniciaba un ataque si se contaba con el apoyo de los dioses. El pueblo era un mero espectador, no tenía derecho a manifestar sus jui-

${ }^{14}$ Estaban los dioses que había creado el hombre como consecuencia de su observación de la naturaleza (Zeus, Hera, Poseidón, Apolo) y los héroes de la ciudad también eran divinizados; tenían esta consideración el fundador de la ciudad, cualquiera que hubiera ganado batallas o hubiera prestado cualquier servicio importante a Atenas.

${ }^{15}$ Areópago o "colina de Ares», era un monte situado al oeste de la Acrópolis de Atenas, sede del Consejo. Según la leyenda, se llamaba así porque Ares había sido juzgado por los dioses y exonerado de ser ajusticiado gracias a la intervención de Halirrhotios, hijo de Poseidón.

${ }^{16}$ FUSTEL DE COULANGES, N.D., op. cit., p. 250.

${ }^{17}$ Como quiera que la religión configuró el régimen político e impregnaba todos los actos y momentos de la vida de los atenienses, la asamblea sólo se podía reunir cuando aquélla lo permitía; siempre comenzaba con un acto religioso en el que los sacerdotes ofrecían un sacrificio y pronunciaban una oración con el pueblo silencioso, también se consultaban los auspicios y si el cielo presentaba algún signo fatídico se disolvía. Todos los oradores disertaban con una corona en la cabeza y durante largo tiempo se recitaba una oración como exordio que precedía al discurso. (FUSTEL DE COULANGES, N.D., op. cit., p. 178.)

${ }^{18}$ Ilíada, 1.68. 
cios de valor sobre los temas objeto de debate, ni de voto para decidir la propuesta que considera más acertada y favorable para el bien común; sólo podía mostrar su aprobación o desaprobación con las propuestas presentadas con silencio, gritando o haciendo ruido con las armas ${ }^{19}$. El basileus, después de conocer el posicionamiento de los eupátridas y del sentir de la comunidad, tenía el poder absoluto para tomar la decisión que estimara oportuna, aunque si iba en contra del pueblo se arriesgaba a un amotinamiento.

\section{II.2. La aristocracia}

Diversas teorías existen sobre los motivos que provocaron que los eupátridas no se sintieran cómodos en la ciudad federal ${ }^{20}$, que habían aceptado constituir de la mano de Teseo y que les permitió conservar su poder omnímodo sobre las comunidades políticas que coexistían en la polis. Este malestar se tradujo en enfrentamientos constantes con los diversos reyes atenienses, hasta que, al morir de Codro (mediados del siglo XI a.C.), consiguieron arrebatarles el poder político. Sin embargo, conservaron el carácter de autoridad religiosa ${ }^{21}$, de modo que aunque los eupátridas gobernaban Atenas, los reyes se sucedieron durante varios siglos encargándose de dirigir el culto a los dioses atenienses hasta que la familia de un monarca se deshonró con un crimen. ${ }^{22}$ Ante este hecho luctuosos los aristoi decidieron privarles de su alta dignidad y, en adelante, la jefatura religiosa fue también ostentada por uno de ellos.

Los eupátridas gobernaban la polis, monopolizaban el poder político y religioso, que se canalizaba a través de tres magistraturas. Ini-

${ }^{19}$ Ilíada, 2.142; 2.207 (rugen como el mar), 2.270 (se rieron), 2.333 (aplaudieron), 2.394 gran clamoreo).

${ }^{20}$ PLUTARCO sostiene que «como los reyes se mostraban orgullosos y duros en el mando, la mayoría de los griegos les despojaron del poder y sólo les dejaron al cuidado de la religión» (Cuestiones romanas, 63). HERÁCLIDES LEMBO dice que «entre los Códridas ya no se eligieron más reyes porque eran presa de la molicie y se habían vuelto blandos» (Epítome, I), FUSTEL DE COULANGES considera que fueron los intentos de Teseo por marginar y desplazar los cultos domésticos a favor de los dioses de la ciudad lo que provocó la animadversión de los aristoi contra el rey. (op. cit., p. 254).

${ }^{21}$ ARISTÓTELES dice que «en tiempos muy antiguos los reyes tenían un poder absoluto en la paz y en la guerra, pero más tarde renunciaron unos a este poder y a otros se les arrancó por la fuerza; y sólo se dejó a estos reyes el cuidado de la religión.» (Política, III, 9,8).

${ }^{22}$ Cfr. DIODORO, Bibliotheca histórica, libro VIII y NICOLÁS DE DAMASCO, Suidas, V, 51. 
cialmente, sus titulares ejercían el cargo durante diez años, pero, posteriormente, fueron anuales; eran elegidos por sorteo de entre los propuestos por los jefes de las familias, y, una vez designados, eran sometidos por el Consejo del Areópago a la dokimasía, que consistía en verificar el linaje y religiosidad de los electos, superada esta prueba, prestaban juramento sobre la piedra de los sacrificios a los dioses $^{23}$. El arconte rey era el sumo pontífice; presidía y dirigía las ceremonias religiosas, fiscalizaba la administración de los bienes de los templos y ejercía funciones judiciales derivadas de los litigios surgidos en las liturgias; el arconte polemarco era el jefe del ejército, se encargaba de la seguridad de la ciudad en tiempos de paz y de dirigir las ofensivas militares en la guerra, asimismo, juzgaba los delitos cometidos por los extranjeros, ciertas causas civiles, incluso de los metecos y presidía actos de homenaje a los soldados muertos en el campo de batalla; el arconte epónimo era el magistrado jefe, llamado así porque su nombre se colocaba en el encabezamiento de los documentos oficiales para datarlos, intervenía en la vida interna de las familias para sancionar los excesos de los padres con los hijos, otorgar protección a los desamparados y establecer las tutelas, con la progresiva complejidad de la administración de Atenas, asumió el ejercicio de aquellas competencias de gobierno que la polis fue requiriendo ${ }^{24}$.

Los eupátridas eran los únicos que conocían las leyes no escritas (tesmoi) porque la religión se las había revelado y habían transmitido su conocimiento de padres a hijos, de modo que sólo ellos administraban justicia. Sin embargo, progresivamente va a ir desligándose del ámbito privado en el que se había desarrollado tradicionalmente, para convertirse en un interés común y así se instauró una jurisdicción pública para toda Atenas, ejercida por la ciudad.

A mediados del siglo VII a.C., fruto de la lucha de clases, se consiguió la publicidad de las leyes, esta tarea fue encargada a seis temostetas, que junto a las otras tres magistraturas formaban el colegio de los nueve arcontes, elegidos entre aquellos eupátridas que tenían unas cualidades especiales para interpretar las creencias religiosas, que eran la fuente del derecho. No obstante, según la tradición, no fue hasta el año 621 a.C. cuando el temosteta Dracón fue ungido con poderes extraordinario para que plasmara en un Código las leyes vi-

${ }^{23}$ ELLUL, J., Historia de las Instituciones de la Antigüedad, traducción de Francisco Tomás y Valiente, Madrid, 1970, p. 38.

${ }^{24}$ BERNABÉ PAJARES, A., Aristóteles, Constitución de los atenienses, Madrid, 2005, p. 183. 
gentes; esta tardanza se atribuye a la reticencia de los aristoi a perder el poder que les otorgaba el ser los únicos que las conocían. ${ }^{25}$

Los seis temostetas formaban parte del Themosthéai, que era un tribunal colegiado encargado del enjuiciamiento de determinados delitos y de causas civiles. Asimismo, el Hoi Tettarakonta era un tribunal itinerante que se iba desplazando por el Ática para enjuiciar pleitos civiles y ciertos delitos. ${ }^{26}$

Ciertamente, existían también otros empleado públicos de menor rango, pero que eran absolutamente necesarios para la vida de la ciudad; verbigracia: los colacretai, cuya misión era seleccionar los animales que se iban a destinar a los sacrificios y auxiliar al arconte rey en dicha ceremonia, y los tamiai, encargados de custodiar del Tesoro.

El Consejo del Areópago estaba formado por los arcontes que dejaban de ejercer las magistraturas; sus miembros, llamados areopagitas, eran vitalicios y se encargaban de controlar que los arcontes cumplieran adecuadamente sus funciones, y, a partir de la codificación de Dracón, se van a ocupar de la custodia de la leyes. Se profundiza en la jurisdicción pública al asumir la competencia de juzgar homicidios premeditados, las lesiones causadas con animus necandi, los incendios de casas habitadas y los envenenamientos. También se continúa en esta línea con la constitución del Tribunal de los Efetas, formado por 51 miembros, ${ }^{27}$ que se reunía en diferentes lugares dependiendo de los asuntos criminales que tenían que enjuiciar: el Paladion, situado en el antiguo santuario de Palas Atenea, era el lugar donde se juzgaban los homicidios involuntarios, y se investigaban los asesinatos y la complicidad en la muerte de cualquier persona, ciudadanos o no; Delfinion, ubicado cerca del templo de Apolo Délfico, en el que se fallaban las causas de homicidio en defensa propia o con diversos atenuantes, tales como accidentes en los juegos, equivocación en el combate, o los casos de flagrante delito de adulterio;

${ }^{25}$ ELLUL, J., op. cit., p. 47.

${ }^{26}$ ALONSO Y ROYANO, F., «El derecho griego», Espacio, Tiempo y Forma, Serie II, Historia Antigua, t. 9, Madrid, 1996, p. 117.

${ }^{27}$ Los tres arcontes y 48 náucraros. «La palabra náucraro parece significar «capitán de barco». Posiblemente en un principio el capitán y el propietario del barco eran idénticos. Atenas no tuvo marina estatal hasta el año 483 a.C. Antes de esa fecha, en tiempo de guerra, se movilizaban buques de personas privadas, llamadas náucraros, organizados en grupos llamados naucrarías. Las naucrarías no eran una división del cuerpo ciudadano, sino agrupaciones de individuos ricos que proveían los buques la flota.» (MUÑOZ VALLE, I., "La reforma social de Solón en la antigua Atenas», Revista de Estudios Políticos. Madrid, 1977, p. 11). 
Freatis, en las orillas del mar en el puerto del Pireo, se enjuiciaba a los exiliados temporalmente por homicidio involuntario, acusados de un nuevo asesinato o de lesiones con premeditación.

En cuanto a la Asamblea (Ekklesia) de la ciudad, durante el régimen aristocrático careció de poder político, y solamente se reunía una vez año para realizar el acto de mero trámite de confirmar el nombramiento de los arcontes. ${ }^{28}$

La gens continuaba siendo una comunidad política con mucho poder sobre todas aquellas personas que, ya sea por vínculo de sangre o de servidumbre, formaban parte de ella porque las antiguas creencias religiosas continuaban estando profundamente arraigadas en las conciencias, condenándoles a estar plenamente sometidos al primogénito-eupátrida sin ser ni siquiera conscientes del embridamiento en el que se encontraban.

La unidad inquebrantable de la familia estaba cimentada sobre el principio de indivisibilidad del caudal relicto, imposibilitando su reparto equitativo entre los hermanos con el fin de que la continuidad del culto estuviera garantizada por el primogénito. Esta regla profundamente injusta y discriminatoria se fue abandonando progresivamente con el paso de los siglos, sin que sea posible ofrecer una fecha exacta de este trascendental cambio, que va a ser el detonante de posteriores revoluciones que van a provocar una mutación radical en la vida política ateniense. Solón aprobó una ley que establecía que «los hermanos se repartieran el patrimonio», pero, a pesar de este tenor literal, el derecho de primogenitura, sustentado en las creencias religiosas, no quedó derogado en su totalidad ya que durante mucho tiempo disfrutará del conocido como privilegio del primogénito, que probablemente consistía en que la casa familiar quedaba excluida del reparto a favor de éste, lo que obligaba a los demás hermanos a fundar un nuevo hogar. ${ }^{29}$ De esta forma la gens tradicional se desmembró en múltiples ramas, cada una de ellas tenía sus propios predios e intereses, y era independiente de la familia original con la que seguían compartiendo las creencias y el culto a los antepasados, pero el vínculo religioso se relajo considerablemente.

La situación de los clientes, objetivamente, había mejorado respecto de la época monárquica debido a que los eupátridas les habían otorgado la posesión de un lote tierras que podían cultivar y construir una casa donde vivir con su familia de forma autónoma respecto

${ }^{28}$ Ibidem, p. 10.

${ }^{29}$ FUSTEL DE COULANGES, N.D., op. cit., p. 102. 
del jefe de la gens, a cambio debían de entregarle la sexta parte de la cosecha (censo). Sin embargo, su percepción subjetiva era mucho más pesimista, angustiosa y desesperada que en épocas pasadas, ya que sabían que nunca podrían llegar a ser propietarios de los predios a los que habían dedicado todo el trabajo de su vida, además, en cualquier momento podían perder ad nutum, por la mera voluntad del aristoi la posesión de las tierras; y en el caso de que no pagaran el censo se veían reducidos a la esclavitud. Esta situación fue el caldo de cultivo perfecto para las revueltas y enfrentamientos con los eupátridas, que se desarrollaron desde el siglo VII al V a.C. ${ }^{30}$, fue un camino difícil y sangriento, pero fructífero, porque paulatinamente fueron alcanzando sus objetivos económicos y políticos.

\section{II.3. La timocracia}

Las clases populares tenían sus propios líderes que dirigían la lucha social para tratar de darle al pueblo el poder del que durante siglos se había visto privado; tras largos y arduos enfrentamientos ${ }^{31}$, en el año 592 a.C. ${ }^{32}$, ambas facciones (demos y eupátridas) acordaron nombrar a Solón, para que reformara el sistema político y tanto el Consejo del Areópago como la Asamblea juraron acatar las reformas solonianas.

En el plano económico ${ }^{33}$, suprimió la responsabilidad personal por impago del censo (seisacteia) y redujo la cuantía del mismo, de

${ }^{30}$ Ibidem, p. 283.

${ }^{31}$ ARISTÓTELES, Constitución de los Atenienses, 2.

${ }^{32}$ Ibidem, 14-1.

${ }^{33}$ En cuanto a la reforma económica, sigo la teoría sostenida por FUSTEL DE COULANGES, por ser la más coherente con los datos y referencias históricas que tenemos sobre la situación social, económica y política de la Atenas que precedió a Solón. No obstante, conviene precisar que la posición de este historiador no es ni mucho menos unánime en la abundante doctrina existente sobre el alcance y las reformas realizadas por Solón. Disiento de la idea de que antes de Solón existían los créditos y las deudas de dinero, tal y como afirma ARISTÓTELES (Constitución de los atenienses, 6) porque no está acreditado que antes del 600 a. C hubiera una circulación de moneda los suficientemente generalizada como para que existieran prestamistas y demanda de préstamos, es probable que el estagirita haya trasladado la Atenas del s. IV a.C. a un tiempo pretérito; es más verosímil que las deudas que había y que canceló Solón fueran las relativas al impago del censo, que habían llevado a la esclavitud a muchos atenienses. Por otra parte, tampoco comparto la afirmación sostenida por algunos historiadores de que originariamente todos los atenienses eran propietarios de pequeños fundos, y que por culpa de las deudas las perdieron, devolviéndoselas Solón, ya que, desde la noche de los tiempos, la titularidad de todos los predios del Ática era de las familias, con el fin de garantizar la unidad de la gens y la continuidad del culto a los 
modo que los clientes y servidores mejoraron su calidad de vida y, sobre todo y más importante, fueron libres; ya no corrían el peligro de ser sometidos a la esclavitud porque un año la cosecha fuera pésima y no pudieran alimentar a su familia y pagar el tributo al eupátrida. Sin embargo, el avance más notable fue el otorgamiento de la propiedad a los clientes de aquellas tierras que llevaban trabajando durante mucho tiempo, para ello arrancó los Términos que delimitaban las propiedades y se las entregó al demos, lo que supuso la eliminación del carácter sagrado que le había atribuido la religión a la propiedad y que impedía su transmisión a terceros ${ }^{34}$. Asimismo, liberó a todos aquellos que habían sido reducidos a la esclavitud por impago del censo y trajo de vuelta a Atenas a todos los que, por este motivo, habían sido vendidos como esclavos en el extranjero, o habían huido para evitar ser reducidos a la servidumbre, cancelando todas las deudas que tuviesen pendientes y les entregó en propiedad las tierras que habían estado trabajando anteriormente.

En el plano político, rompió el binomino religión-poder con el fin de otorgarles derechos políticos tanto a las nuevas ramas escindidas de la gens tradicional, creadas a partir del reparto del caudal relicto entre los hermanos, como a los nuevos ciudadanos libres que habían abandonado la clientela, de modo que el poder político ya no era un privilegio del nacimiento concedido por la religión, sino que estableció un nuevo criterio: la riqueza. Sin embargo, aunque teóricamente supuso un cambio, ya que el acceso a los cargos políticos dependía de la capacidad adquisitiva y no de la cuna, en la práctica, los aristoi siguieron en gran medida monopolizando el poder político, porque eran terratenientes y atesoraban grandes riquezas.

La timocracia se sustentaba sobre la base de la división de la población en cuatro clases censitarias: los pentacosiomedimnos eran los que obtenían quinientos medimnos ${ }^{35}$; los hippeis eran aquellos que producían más de trescientos medimnos y podían permitirse un caballo, pertenecían a la caballería y sus obligaciones militares eran el

antepasados, no existía un derecho subjetivo de propiedad. De modo que Solón no les devolvió la propiedad, porque nunca la habían tenido, sino que se la otorgó por primera vez.

${ }^{34}$ Solón en alguno de sus versos dice: «era un paso inesperado; yo lo he dado con ayuda de los dioses. Pongo por testigo a la diosa madre, a la negra Tierra, a la que muchos parajes le he arrancado los términos, la tierra que era esclava y al presente libre». "A los que sufrían cruel servidumbre en esta tierra, y temblaban ante un amo yo los he hecho libre.» ARISTÓTELES considera que "puso fin a la esclavitud del pueblo.» (Politica, II, 9,2.)

${ }^{35} \mathrm{El}$ medimno era una medida para sólidos equivalente a $52 \mathrm{Kg}$. 
aprovisionamiento a los hoplitas; los zeugitai eran los que producían entre doscientos y trescientos medimnos, eran los agricultores y campesinos, propietarios de una yunta de bueyes y podían costearse la panoplia y formaban parte de los hoplitas; los thetes eran jornaleros que obtenían menos de doscientos medimnos, fueron muy necesarios en el ambiente bélico que vivió Atenas porque eran los remeros de la flota.

Las magistraturas superiores eran las siguientes; los nueve arcontes, los intendentes ${ }^{36}$, los contratistas públicos, lo Once ${ }^{37}$ y los recaudadores. Estaban ocupadas por los pentacosiomedimnos, hippeis y zeugitas, elegidos por sortero de entre los propuestos por cada una de las tribus. El cargo público más importante era el de arconte pero sólo podían optar al mismo los pentacosiomedimnos. ${ }^{38}$

Solón positivizó las leyes civiles y penales ${ }^{39}$, sin embargo, la aportación más relevante y que inició el camino hacia democracia, fue la creación de los dikasterios: ${ }^{40}$ eran tribunales populares formados por ciudadanos que asumieron la potestad jurisdiccional en materia penal y civil, sin perjuicio de que tanto el Consejo del Areópago como el Tribunal de Efetas conservaron sus competencias judiciales. Según ARISTÓTELES ${ }^{41}$, Solón contribuyó a que este poder atribuido al pueblo tuviera mucha repercusión social, al establecer leyes oscuras que provocaron una gran cantidad de litigios resueltos por los ciudadanos. Por otra parte, el estagirita afirma que concedió a los ciudadanos la potestad de fiscalizar la actividad realizada por los magistrados ${ }^{42}$, que debían comparecer ante los dikasterios, lo que fortaleció la posición del pueblo frente a los eupátridas, impidiendo que utilizaran el cargo en su propio beneficio.

${ }^{36}$ Tesoreros que custodiaban las abundantes alhajas y demás efectos valiosos que había en el templo de Atenea. Los tesoros de los otros templos en ocasiones eran administrados de forma conjunta junto con el de Atenea y a veces también por cargos distintos. (RHODES, P.J, A Commentary of the Aristotelian Athenaion Politeia, Oxford, 1981, pags. 549 ss.).

${ }^{37}$ Se encargaban de la prisión, de dar muerte a los ladrones, a los que hayan reducido a otros a la esclavitud y a los salteadores que les traigan detenidos, si reconocen su culpabilidad, o enviarlos al tribunal en caso contrario y ponerles en libertad si fueran absueltos. (ARISTÓTELES, Constitución de los Atenienses, 52-I).

${ }^{38}$ STOCKTON, D., The Classical Athenian Democracy, Oxford Univ. Press, 1990. p. 29. Asimismo, considera que probablemente los hippies accedieron al cargo de arconte en tiempos de Clístenes.

${ }^{39}$ SAYAS ABENGOCHEA, J. J., "Atenas y Esparta», Grandes imperios y civilizaciones, Navarra, 1991, p. 44.

${ }^{40}$ ARISTÓTELES, Política, 1273b.

${ }^{41}$ ARISTÓTELES, Constitución de los Atenienses, 9-1.

${ }^{42}$ Política, 1274a. 
El Consejo del Areópago seguía formado por exarcontes y realizando las funciones que desempeñaba tradicionalmente. El Consejo de los Cuatrocientos (Boulé) ${ }^{43}$, estaba compuesto por cien ciudadanos atenienses de cada una de las cuatro tribus, elegidos por sorteo ${ }^{44}$, no tenemos conocimiento de cuáles eran sus funciones, llegando incluso por algunos autores a poner en duda su propia existencia, y la Ekklesia no debió de tener relevancia en este período. ${ }^{45}$

A pesar de la profunda reforma, Solón no suprimió la organización política-religiosa de Atenas, de modo que la religión siguió ejerciendo una fuerte presión sobre la sociedad, permitiendo que los aristoi aún retuvieran importantes cotas de poder y de influencia sobre el pueblo, que se había liberado de las cadenas de la servidumbre y había alcanzado la libertad, pero que en su mayor parte estaba incorporado a una de las múltiples gens y, por tanto, sometido y subordinado a la autoridad de un eupátrida. ${ }^{46}$ Bien es cierto que al liberarse del yugo clientelar, los atenienses eran libres para desligarse de la familia tradicional a la que habían pertenecido, pero aquellos que osaron independizarse cayeron en la más absoluta ignominia y fueron despreciados y marginados por el resto.

La reforma económica y política soloniana merece una valoración positiva porque otorgó la libertad al pueblo y le concedió derechos políticos. No obstante, los profundos cambios en el régimen político no contentaron a nadie: los eupátridas los consideraban exagerados y les habían causado la perdida de importantes cotas de poder, y el demos los consideraba insuficientes, ya que había abrigado la esperanza de que se produjera el reparto de la tierra del Ática, como en Esparta, donde los ciudadanos, llamados iguales, eran propietarios de lotes de tierra iguales ${ }^{47}$, pero nunca se produjo porque Solón no pensaba que debieran participar por igual en la posesión de la tierras los aristo $i$ y el pueblo, de manera que siguió habiendo profundas desigualdades económicas.

${ }^{43}$ PLUTARCO, Solón, 19.

${ }^{44}$ RODRÍGUEZ ADRADOS considera que eran elegidos directamente por el propio Solón, de por vida (Historia de la Democracia: De Solón a nuestros días, Madrid, 1997, p. 42).

${ }^{45}$ ELLUL, J, op. cit., p.48.

46 «Estas ligado al eupátrida por el culto, le debes respeto, deferencia, sumisión; como miembro de una ciudad, Solón te ha hecho libre, pero como miembro de un tribu has de obedecer a un eupátrida; como miembro de una fratría has de tener un eupátrida por jefe y en la misma familia, en la gens donde tus antepasados nacieron y de la que tú no puedes salir también encuentras la autoridad del eupátrida.» (FUSTEL DE COULANGES, N.D., op. cit., p. 287-288).

${ }^{47}$ PLUTARCO, Solón, 16. 
Solón podría haberse convertido en un tirano simplemente acercándose a cualquiera de las dos facciones, sin embargo, no sucumbió a la tentación del poder omnímodo y decidió legislar según su saber y entender, aunque eso le granjera la enemistad y el enfrentamiento con todos. Una vez que estableció el nuevo régimen político, partió para Egipto para evitar las presiones a las que estaba siendo sometido por todos para que modificara tal o cual ley, o para que aprobara otras. En su ausencia, volvieron los enfrentamientos, y diversos grupos trataron de hacerse con el poder. Finalmente, el tirano Pisístrato, apoyado por el demos empobrecido, consiguió ocupar la acrópolis y convertirse en dictador. Su gobierno fue muy accidentado y pasó muchas dificultades para consolidarlo, teniendo que exiliarse en dos ocasiones. Respetó las leyes solonianas y dedicó sus esfuerzos a los intereses de la ciudad en vez de a los suyos particulares, lo que no impidió que se enriqueciera al obligar a los agricultores a entregarle un diezmo de sus cosechas.

Al morir Pisístrato, le sucedieron sus dos hijos, Hisias e Hiparco, acostumbrados al poder, ejercieron la tiranía como su padre. Las familias aristocráticas reivindicaron ostentar altos cargos en el gobierno, pero sus pretensiones no fueron escuchadas. Hiparco fue asesinado por un asunto amoroso y finalmente Hisias fue derrocado gracias a la intervención del rey de Esparta Cleómedes a instancias de los eupátridas atenienses.

In illo tempore, se empezaron a acuñar monedas de plata, famosas por la alta calidad de su aleación y por su elegante troquelación, y con ellas surge el dinero como medio de cambio, desplazando a la tierra como símbolo de riqueza; al ser una res nec mancipi se transmitía por la simple traditio impidiendo la influencia de la religión, lo que unido al desarrollo del incipiente comercio marítimo ateniense y de la artesanía, permitió que antiguos clientes, ahora hombres libres, hicieran importantes fortunas ${ }^{48} \mathrm{y}$ así pudieron acceder a las magistraturas superiores.

\section{II.4. La reforma democrática de Clístenes}

Derrocado Hipias en el 510 a.C., se enfrentaron por el poder dos facciones aristocráticas: Clístenes, de la familia de los Alcmeónida e Iságoras, amigo del rey espartano Cleómedes, amistad que le permi-

${ }^{48}$ FUSTEL DE COULANGES, N.D., op. cit., p. 280. 
tió ser nombrado tirano ante el riesgo de que el ejército espartano sitiara la ciudad. Según ARISTÓTELES ${ }^{49}$, cuando Clístenes fue obligado al exilio, la mayor parte del demos se sublevó contra Iságoras y sus partidarios haciéndose con el poder, y se lo entregaron a Clístenes ${ }^{50}$; esta afinidad de las masas populares fue debida a que los Alcmeónidas siempre habían luchado contra los tiranos.

La organización política se cimentó sobre un nuevo diseño territorial de la polis; Clístenes la dividió en treinta partes llamadas tercios: diez del distrito de la ciudad, diez del de la costa y diez del de tierra adentro, el territorio de cada una de las diez nuevas tribus estaba formado por tres tercios, uno por cada distrito, elegidos al $a a^{51}$, cada distrito estaba formado por un determinado número de demos (municipios), para eliminar las antiguas gens. De modo que cada tribu estaba formada por ciudadanos de toda la geografía y de cualquier condición, suprimiéndose el nacimiento como criterio que tradicionalmente había determinado la pertenencia a una tribu, por el del domicilio y se derogaron todos los privilegios que la religión había otorgado desde tiempos inmemoriales al primogénito. La religión de cada tribu y demo cambió, ya no eran los antepasados divinos del eupátrida a los que había que rendir culto, sino que cada tribu eligió a un héroe epónimo del pasado de Atenas y lo convirtió en la figura divina a la que adorar y venerar; los demos de la ciudad eligieron como dioses comunes a Zeus y a Apolo. En esta nueva organización territorial del poder, la jefatura de la tribu y de los demos y el cargo de sacerdote ya no eran hereditarios, sino cargos anuales que podía desempeñar cualquier miembro de la tribu ${ }^{52}$. Clístenes liberó definitivamente al pueblo del yugo opresor de los eupátridas, gracias a un cambio en las creencias religiosas que eran las que legitimaban el poder de los aristoi.

En este nuevo régimen, la religión y la tradición dejaron de ser el principio que, durante muchos siglos, había inspirado el gobierno de la ciudad, y son sustituidas por el interés público. Cuando hay que tomar una decisión política ya no se vuelve la mirada hacia la religión para ver lo que prescribe, sino que se trata de adoptar aquélla que sea más favorable al interés general de los ciudadanos. Como quiera que

${ }^{49}$ Constitución de los atenienses, 20-3 y 4.

${ }^{50}$ Clístenes no recibió el encargo de legislar como le ocurrió a Solón, sino que todas las reformas se aprobaron por leyes de la Asamblea (nomoi). (PAJARES BERNABÉ, A., op. cit., p.168).

${ }^{51}$ ARISTÓTELES, Constitución de los atenienses, 21-4.

${ }^{52}$ FUSTEL DE COULANGES, N.D., op. cit., p. 288. 
las prescripciones de la religión son claras, diáfanas y evidentes para aquellos que están ungidos con los dones divinos (eupátridas), eran ellos los que unilateralmente decidían todas las cuestiones relativas al gobierno y la administración de la ciudad. No obstante, determinar qué medida contribuirá de forma más satisfactoria al interés público ya no es tan palmario y por ello, se hace necesario consultar a los ciudadanos, es decir, tiene que haber un debate público de ideas en el que cualquiera pueda exponer las razones o motivos por los que considera que tal o cual decisión reportará mayor bienestar al conjunto de la población.

La reforma política clisteniana ${ }^{53}$ fue de gran envergadura al continuar el camino iniciado por Solón hacia la democracia; convirtió la asamblea en el centro del poder político, pero todavía perduraron las profundas discriminaciones en el acceso a los cargos públicos que se encargaban del gobierno y la administración de la res publica ateniense. Los aspectos más sobresalientes fueron los siguientes:

- Mantuvo la división censitaria de la población soloniana, pero amplio el acceso al cargo de arconte a los hippeis. Las magistrados eran elegidos por la Ekklesia, lo que no impidió que los eupátridas siguieran instalados en el poder político porque sus candidaturas eran apoyadas por los jornaleros que dependían de ellos.

- En el ámbito militar, cada una de las diez tribus elegía a un strategos, jefe del ejército de la tribu. Los diez strategos dependían jerárquicamente del arconte polemarco, comandante en jefe de todas las fuerzas armadas de Atenas.

- Profundizó en la igualdad de derechos políticos, atribuyendo la ciudadanía ateniense a muchos esclavos y extranjeros ${ }^{54}$, pero no a las mujeres. Su integración en alguna de las diez tribus no planteó problemas al no estar constituidas por vínculos de sangre como ocurría tradicionalmente.

- Con el objeto de proteger el nacimiento de la incipiente democracia, se promulgó la ley sobre el ostracismo ${ }^{55}$, una institución cuyo objeto era librar a Atenas de los tiranos que habían sido una lacra para la polis. El pueblo era soberano para

${ }^{53}$ Sobre el alcance de las reformas de Clístenes, cfr. RHODES, P.J, op. cit., p. 251 SS.

${ }^{54}$ ARISTÓTELES, Política, III, 2, 3, $1275 \mathrm{~b} 45$ ss.

${ }^{55}$ ARISTÓTELES, Constitución de los atenienses, 22-3. 
decidir si alguna persona era peligrosa, en el sentido de que pudiera tener como aspiraciones constituirse en dictador. El procedimiento era el siguiente: una vez al año se sometía a votación en la Ekklesia si se consideraba pertinente abrir un proceso de ostracismo, en caso afirmativo se producía una nueva votación en la que cada miembro de la asamblea podía escribir en la ostraka (pedazo de cerámica) el nombre de algún ciudadano, si había más de seis mil, los arcontes procedían a contar cuál había sido escrito más veces y ése era condenado al exilio durante diez años, conservando la propiedad de sus bienes situados en Atenas, pero no podía disfrutarlos ni tampoco ejercitar sus derechos políticos durante el tiempo del destierro ${ }^{56}$. En épocas posteriores, fue sin duda un arma poderosa que el pueblo utilizó contra numerosos políticos.

Profundizó en la igualdad de derechos políticos, atribuyendo la ciudadanía ateniense a muchos esclavos y metecos, pero no a las mujeres. Su integración en alguna de las diez tribus no planteó problemas al no estar constituidas por vínculos de sangre como ocurría tradicionalmente.

Clístenes estableció el Consejo de los Quinientos (Boulé) ${ }^{57}$, órgano de gobierno de Atenas, estaba formado por cincuenta ciudadanos mayores de treinta años de cada una de las diez tribus, elegidos por sorteo de entre los que voluntariamente quisieran optar al cargo. De entre sus funciones, destacan por su importancia las siguientes: la elaboración de proyectos de ley para su posterior debate y votación en la Asamblea, el examen moral de los magistrados antes de acceder al cargo y la fiscalización de su gestión, la elaboración de informes sobre política exterior para la Asamblea y la verificación de que el culto a los dioses atenienses se practicara convenientemente. ${ }^{58}$ Recortó de manera sensible los poderes del Consejo del Areópago, formado por exarcontes, perdiendo toda su importancia política en favor de la Boulé, pero conservó su función de custodiar las leyes y el enjuiciamiento de los homicidios. Asimismo, los dikasterios siguieron siendo tribunales populares encargados de ejercer la potestad jurisdiccional.

La Asamblea (Ekklesia) era la institución en la que se tomaban las decisiones políticas relativas a los asuntos públicos de Atenas. Estaba formada, igual que en tiempos de Solón, por todos los ciudadanos, se

\footnotetext{
${ }^{56}$ SAYAS ABENGOCHEA, J.J., op. cit. p. 51.

${ }^{57}$ ARISTÓTELES, Constitución de los atenienses, 21.3.

${ }^{58}$ ELLUL, J., op. cit., p. 90.
} 
reunía unas diez veces al año; tenía potestad legislativa y, entre otras funciones, se encargaba de decidir sobre la declaración de guerra o la concertación de un tratado de paz, así como de resolver todas las demás cuestiones relativas a las relaciones exteriores de la polis. Las sesiones de la Ekklesia se desarrollaban sobre la base de la isegoría: ${ }^{59}$ todos los ciudadanos tenían derecho a disertar sobre la materia objeto de debate, sus opiniones tenían igual valor porque se reconoció el derecho de voto para decidir sobre los asuntos que afectaran a la comunidad política en la proporción de un ciudadano un voto.

\section{LA DEMOCRACIA ATENIENSE}

Al vencer Atenas en las dos Guerras Médicas (490 y 480 a.C.). ${ }^{60}$ se convirtió en la primera potencia militar de Grecia, desplazando a Esparta, haciéndose con el liderazgo de la Liga de Delos, lo que le permitió disponer libremente de los tributos que anualmente todas las ciudades jonias, que formaban parte de la confederación, debían aportar para la construcción de navíos y el sufragio de los gastos militares, con el fin de defenderlas de los ataques persas y realizar campañas dirigidas a conquistar nuevos territorios.

Tras las Guerras Médicas, el Consejo del Areópago se hizo con el gobierno de la polis (478-462 a.C.), al haberse ganado la confianza del pueblo en la batalla de Salamina, porque cuando los generales apostaban por desertar y que cada cual tratase de salvar la vida, apoyó la resistencia de Atenas dando fondos a los generales y obligándoles a capitanear las naves hacia el combate contra los persas.

La democracia directa ateniense tiene su inicio en el año 462 a.C., fecha en la que Efiales devolvió al pueblo el poder político que el Consejo del Areópago le había usurpado, costándole la muerte, al

${ }^{59}$ ALMANDÓS, L., «Igualdad y diferencia en la democracia ateniense», Serie Encuentros, Tesis laureadas, Facultad de Ciencias Humanas, Bogotá, 2003, p.112.

${ }^{60}$ En el año 479 a. C se inicia la Pentotecia, período de máximo esplendor de Atenas. Se extiende hasta el 431 a. C, fecha en la que se inicia la Guerra del Peloponeso. Esta Edad de Oro ateniense es debida a su liderazgo de la Liga de Delos (disuelta en el año 404 a. C, en el que Esparta vence a Atenas, pero renació en el 377 hasta el 338 a. C) lo que le proporcionó ingentes cantidades de recursos que fueron utilizados para sostener y mantener la democracia, ya que con ese dinero se pudo pagar por ejercer las magistraturas, acudir a las Asambleas y ejercer de jueces en los tribunales populares. Sin él, este sistema político no hubiera gozado ni de la vitalidad que tuvo, ni de la fuerza con la que arraigó. Asimismo, se empleó para embellecer la polis, hacer espléndidas y majestuosas fiestas y procesiones en honor de los dioses, disfrutar de pantagruélicos y opíparos banquetes, etc. 
ser asesinado por uno de los areopagitas a los que había destituido, y se prolongará en el tiempo hasta el año 328 a.C., fecha en la que Filipo II de Macedonia derrota a Atenas en la batalla de Queronea. Durante casi ciento cuarenta años, con un par de breves interrupciones oligárquicas, Atenas gozará del mayor grado de autogobierno jamás conocido, habrá una mayoritaria participación de los ciudadanos en las instituciones políticas democráticas. Por tanto, será la voz del pueblo, pobres y ricos, todos juntos en un plano de igualdad, la que decida cómo ha de gobernarse la ciudad-estado.

A la muerte de Efiales (461 a.C.), le sucede Pericles que continuó en la línea reformista, con medidas dirigidas inequívocamente a profundizar y consolidar la democracia participativa como el régimen político que iba a regir la vida de Atenas.

En tiempos de este estadista, se consiguió la isonomía ${ }^{61}$ (igualdad ante la ley) entre ciudadanos porque no sólo permitió el acceso a las magistraturas superiores (arconte e intendente) a los zeugitas ${ }^{62}$, sino que, por primera vez en la historia de Atenas, liberó de su marginación a los thetes: los más pobres, permitiéndoles el acceso a todas las magistraturas ordinarias, y en cuanto a las superiores, podían alcanzar el cargo de intendente ${ }^{63}$, pero desconocemos si también el de arconte. No obstante, considero que podían ingresar en el mismo porque; por una parte, esta alta magistratura había perdido el poder político que tradicionalmente había ostentado en favor de los diez strategos, generales del ejército ateniense, y, por otra, eran elegidos por sorteo, de modo que no se requería ninguna cualificación especial para su ejercicio, ya que de lo contrario habrían sido nombrados por la Ekklesia como los strategos; para poder optar a este cargo tenían que concurrir en los candidatos unas especiales habilidades y destrezas bélicas, lo que es coherente porque estamos en un período de hegemonía militar de Atenas, que había asumido la dirección de la Liga de Delos, y de gran conflictividad bélica.

El sistema de designación de los titulares de las magistraturas era por sorteo entre los ciudadanos, excepto la de strategos, jefes de la caballería, el encargado de la subvención de los espectáculos públicos

${ }^{61}$ HERODOTO dice que «el gobierno del pueblo tiene, de entrada, el nombre más hermoso del mundo: isonomía; y, por otra parte, no incurre en ninguno de los desafueros que comete el monarca: las magistraturas se desempeñan por sorteo, cada uno rinde cuentas de su cargo y todas las deliberaciones se someten a la comunidad.» (3. 80.6)

${ }^{62}$ ARISTÓTELES, Constitución de los Atenienses, 26-2.

${ }^{63}$ Ibidem, 47-1. 
y el de las fuentes ${ }^{64}$, elegidos por la Asamblea. ${ }^{65}$ Sin duda estamos ante una concepción radical de la igualdad de derechos y de oportunidades, que supone la supresión del carácter aristocrático que impregna el sistema de elección, y que en la práctica no sitúa en el poder a los que objetivamente son los más idóneos, sino a los que subjetivamente la mayoría cree que son los mejores, lo que sin duda abre las puertas a las presiones y captaciones de la voluntad para conseguir los votos y, por tanto, provoca que el poder político se concentre siempre en las manos de los poderosos, impidiendo el acceso a los cargos públicos a los demás ciudadanos.

Los magistrados designados eran sometidos por la Boulé a un control formal de idoneidad, dirigido a verificar que habían cumplido todas sus obligaciones como ciudadanos. Al término del ejercicio de su magistratura, tenía que rendir cuentas ante este órgano de la actividad realizada (dokimasía) y someterse a las quejas que cualquier ciudadano podía presentar en ese momento sobre cualquier aspecto de su acción pública, en el caso de ser fundadas se le podía procesar por la infracción cometida. ${ }^{66}$

En el año 451 a.C., Pericles consiguió que la Ekklesia aprobara una ley que restringía la condición de ciudadano al varón mayor de dieciocho años, cuyos dos abuelos varones (paterno y materno) hubieran estado registrados en alguna demo. ${ }^{67}$ Conviene analizar cuáles pudieron ser las razones que le llevaron a privar de la ciudadanía a los metecos y los esclavos, porque nos revelará la calidad democrática de Atenas, para ello, hay que tener en cuenta cuál era su régimen jurídico.

Los metecos eran extranjeros que necesitaban a un protector (próstata) para poderse inscribir y residir legalmente en alguna demo de Atenas, no podían ser propietarios de predios, por lo que eran arrendatarios del próstata y se dedicaban a la artesanía o al comercio, llegando en ocasiones a poseer importantes fortunas; pagaban tributos, prestaban sus servicios en el ejército como hoplitas o remeros, en el caso de ser llevados ante un tribunal tenían que ser defendidos por el protector. Se calcula que había en Atenas unos diez mil metecos ${ }^{68}$,

${ }^{64}$ Es el que se encarga de gestionar los recursos hídricos de la polis, cargo importante habida cuenta de la escasez de agua.

${ }^{65}$ Ibidem, 44-4.

${ }^{66}$ MOSSÉ, C., Historia de la democracia ateniense, traducción Juan M. Azpitarte Almagro, Madrid, 1987, p. 42.

${ }^{67}$ PLUTARCO, Pericles, 37.

${ }^{68}$ Los datos son de STOCKTON (op. cit. p. 62) 
lo que significa que podían influir de manera decisiva en la toma de decisiones políticas de la Ekklesia, esto probablemente era utilizado por los plousioi (los ricos) ${ }^{69}$ para incrementar su poder en la Asamblea, ya que eran los que tenían a su cargo a los metecos, que se encontraban en una situación de dependencia y subordinación absoluta a su protector, porque sin él no podían vivir en Atenas. Ante esta situación, la finalidad perseguida por Pericles pudo haber sido favorecer a la clase media ${ }^{70}$ y al demos ${ }^{71}$ para que su voz y su voto tuviera más fuerza e influencia en la política ateniense.

El esclavo era un extranjero no residente, no era considerado ni siquiera persona, era una simple mercancía lista y dispuesta para comerciar con ella en los mercados o capturarla como una parte más del botín de una batalla victoriosa. Se encargaban de los trabajos domésticos, de la extracción de plata en las minas, de la artesanía, eran la auténtica fuerza productiva de Atenas, su economía dependía de ellos; y, a su vez, liberaba a la aristocracia ateniense, que eran los que podían comprar y mantener a los esclavos, del trabajo y podían dedicarse, a tiempo completo, a la política; esto les situaba en una situación de superioridad numérica en la Asamblea frente a las clases populares, y si además le adicionamos el poder sobre el voto de los esclavos, ya tenían el control absoluto de la Ekklesia. Por ello, con esta medida Pericles trata de impedir, en la medida de lo posible, que las diferencias económicas no transformen en la práctica la democracia en una férrea oligarquía.

${ }^{69}$ También denominados euporoi (de buenos recursos), oligoi (los pocos) y aristoi (los mejores). Generalmente eran terratenientes, aunque también algunos hicieron grandes fortunas con el comercio del mármol y de las monedas de plata. Se estima que en el siglo V a.C. en Atenas había unos 40.000 ciudadanos, y después de la Guerra del Peloponeso se redujeron a 30.000, de los cuales sólo entre el 5\% y el 10\% formaban parte de esta clase social (DAVIES, J.K., Athenian Propertied Families, 600-300 B.C, Oxford, 1971.)

${ }^{70}$ Entre 8.000 y 10.000 ciudadanos eran zeugitai, (ibídem), propietarios agrícolas de una cierta entidad que no estaban ociosos todo el día porque tenían que trabajar para vivir, pero su situación económica no era tan asfixiante como la del demos y podían permitirse acudir de vez en cuando a la Ekklesia. ARISTÓTELES valora muy positivamente a esta clase media al considerar que «la mejor sociedad no sólo es aquella en la que 'los del medio' tienen la dirección del Estado, sino donde la mayoría pertenecen a esta clase. No hay ciudad donde unos envidian y otros desprecian.» (Política, 1295b).

${ }^{71}$ Igualmente llamados oi polloi (los muchos) pletos (la plebe). Más de la mitad de los ciudadanos atenienses eran pobres y apenas tenían para subsistir; en este estrato social se encontraban aquellos labradores propietarios de una ínfima extensión de terreno para procurar el sustento a su familia, los artesanos y los jornaleros. 
En esta misma línea, logró que se aprobara la institución de la mistoforia, que consistía en fijar una retribución por el ejercicio de las magistraturas, con el fin de que los pobres pudieran participaran activamente en la vida política, y así, de esta forma, los cargos públicos no estuvieran monopolizadas por los pluosioi. La mistoforia contribuyó de forma importante a la consolidación de la democracia, porque permitió que la igualdad de derechos políticos, en cuanto al poder ejecutivo se refiere, no se quedara en una mera declaración programática o de intenciones, sino que fuera real y efectiva.

\section{III.1. Las instituciones políticas}

\section{III.1.A. La Boulé}

La Boulé o el Consejo de los Quinientos era el órgano de gobierno de Atenas, estaba formada por quinientos bouletes, cincuenta ciudadanos de cada una de las diez tribus, designados por sorteo para ejercer el cargo durante un año. Con el fin de agilizar el funcionamiento del Consejo, había una Comisión Permanente ocupada por turnos por cincuenta bouletes de cada tribu, llamados pritanos, durante una décima parte del año (pritanía). Su presidente era elegido por sorteo diariamente ${ }^{72}$, sólo se podía ejercer este cargo una vez en la vida, se encargaba de convocar la sesiones de la Boulé y la Asamblea y de dirigirlas: exponía los asuntos que habían de someterse a deliberación, escrutaba los votos, mantenía el orden, levantaba la sesión etc. ${ }^{73}$

${ }^{72}$ Como el cargo de presidente se renovaba cada día, no todos los ciudadanos que lo ejercieron estaban dotados de las cualidades políticas idóneas para ejercerlo. Esto le debió ocurrir a Sócrates: My dear Polus, I am not a political person and last year having been chosen by lot to serve on the Council, when my tribe was presiding and [as chairman or epistatês] I had to put a question to the vote, I provided everybody with a laugh because I did not know how to do so. «Mi querido Polus, no soy una persona política y el año pasado al haber sido elegido por sorteo para servir en el Consejo, cuando mi tribu alcanzó la presidencia, y como presidente he tenido que formular una pregunta a votación, yo siempre con todo el mundo una risa porque no sabía cómo hacerlo.» (Platón, Gorgias, 473e 6).

${ }^{73}$ Asimismo, se encargaba de custodiar las llaves de los templos, donde se encontraban los recursos económicos, los registros y el sello Atenas. Thus the reins of Athenian government were in the hands of a different Athenian citizen every day of the year.El presidente estaba en el ejercicio de sus funciones las veinticuatro horas que duraba su cargo junto con un tercio de los bouletes de su tribu. Se alojaban en el Tholos o «Casa Redonda». La finalidad era que siempre y en cualquier momento una parte del gobierno estuviera disponible para hacer frente a cualquier situación de emergencia. 
Por sorteo se elegía al secretario del Consejo Permanente, era el depositario de los documentos, custodiaba los decretos dictados ${ }^{74}$ y le prestaba la asistencia que necesitara. En cambio, el pueblo elegía a un secretario que se encargaba de leer en voz alta los documentos tanto al Consejo como a la Asamblea.

Las sesiones de la Boulé se celebraban todos los días, excepto los festivos, sólo podían acudir los miembros de la Comisión Permanente más un representante de cada una de las restantes nueve tribus, elegido por sorteo cada día por el presidente, pudiendo serlo sólo una vez en cada Comisión. ${ }^{75}$ Su función más importante era la de preparar los asuntos que iban a formar parte del orden del día de la Asamblea, que sólo podía pronunciarse sobre aquellas cuestiones que previamente habían sido debatidas en el Consejo Permanente.

El titular del poder legislativo era la Ekklesia, pero sólo podía someter a debate y discusión los proyectos que le presentaba la Boulé. Ahora bien, la iniciativa también se residenciaba en cualquier ciudadano, que estaba legitimado para presentar una propuesta de una ley a la Ekklesia, que se la enviaba a la Boulé para su estudio, y sólo si posteriormente era incluida en un orden del día la Asamblea se pronunciaría sobre ella.

Sus funciones judiciales estaban circunscritas al enjuiciamiento de las infracciones que hubieran cometido los magistrados que disponían de fondos para el ejercicio de sus funciones, y en el caso de resultar condenados podían apelar ante el dikasterio. ${ }^{76}$ Sus competencias en materia financiera se limitan a fiscalizar que la ciudad percibiera todos los ingresos públicos que conforme a las leyes le correspondían. Asimismo, colaboraba con mayor o menor intensidad con múltiples magistraturas civiles.

En cuanto a las decisiones de mayor calado político para la polis, verbigracia: las declaraciones de guerra, la concertación de tratados de paz, el establecimiento de alianzas, la imposición de nuevos tributos, eran tomadas por la Asamblea y su papel se reducía a realizar las propuestas sobre estos asuntos públicos.

${ }^{74}$ Lo que significa que se quedaba con una copia, tanto de los decretos que se grababan en piedra como de los que no. (BERNABE PAJARES, A, op. cit., p. 224).

${ }^{75}$ ALMANDÓS, L., op. cit., p. 174.

${ }^{76}$ ARISTÓTELES, Constitución de los atenienses, 45-2. 


\section{III.1.B. La Ekklesia}

La Asamblea o Ekklesia era el órgano soberano, el centro del poder político. Estaba formada por todos los ciudadanos mayores de dieciocho años; se reunía cuatro veces en cada pritanía en la colina de Pnix ${ }^{77}$, previa convocatoria y fijación del orden del día por el presidente del Consejo Permanente de la Boulép ${ }^{78}$. En los debates todos los ciudadanos gozaban de libertad de expresión para exponer sus juicios de valor sobre las diferentes propuestas objeto de discusión; sólo se le podía retirar la palabra a un ciudadano por decisión del presidente, y únicamente cuando el orador se comportaba de manera indecorosa, en cuyo caso también se le sancionaba con la expulsión de la Asamblea e incluso, según la gravedad del incidente, con una multa.

En cuanto al voto, generalmente se realizaba a mano alzada y todos tenían igual valor; era secreto cuando el objeto de la votación afectaba al interés personal, verbigracia cuando se decidía sobre el ostracismo.

${ }^{77}$ Ibidem, 43-3. Esta periodicidad se refiere al siglo IV a.C, desconocemos la frecuencia con que se eunía en el siglo V a.C.

${ }^{78} \mathrm{La}$ Asamblea se reunía en el recinto consagrado por la religión, desde por la mañana, los sacerdotes daban la vuelta al Pnix inmolando víctimas e invocando la protección de los dioses. El pueblo tomaba asiento en los bancos de piedra (desconocemos cómo se controlaba el acceso a la Ekklesia, con el fin de que no asistieran personas que carecieran de derechos políticos, se ha planteado que cada una de las tribus tenía unos determinados asientos reservados, de modo que al tener la tribu unos tres mil ciudadanos era bastante difícil que no se identificara a alguien que no perteneciera a ella, OBER, J., Mass and Elite in Democratic Athens, Princeton University Press, 1989, p. 132), y en una especie de estrado se colocaban los pritanos que presidían la Asamblea.C.uando todos se habían sentado, un sacerdote alzaba la voz y exclamaba: «Guardad silencio, silencio religioso; rogad a los dioses y a las diosas (nombrando a las principales divinidades del país) a fin de que todo ocurra bien en esta Asamblea para el mayor beneficio de Atenas y de todos sus ciudadanos». El pueblo o alguien en su nombre respondía: «Invocamos a los dioses para que protejan la ciudad. ¡Que prevalezca el dictamen del más sabio! ¡Sea maldito el que nos de malos consejos, el que revele nuestros secretos al enemigo!» (DEMÓSTENES, De falsa legatione, 70, POLUX, VIII, 160). Empezaba la discusión después de que el heraldo había leído el proyecto y decía: «Quien quiere tomar la palabra» y los oradores subían a la tribuna por orden de edad; podían hablar todos sin distinción de fortuna ni de profesión. El pueblo siempre quiso que se le explicaran los asuntos públicos de forma completa con los pros y los contras de adoptar una u otra decisión; escuchaba atentamente a todos los oradores y nunca se formaban tumultos ni conflictos. (FUSTEL DE COULANGES, N.D., op. cit., p. 328). El ciudadano ateniense tenía mucho interés por valorar todos los argumentos para luego votar en conciencia, sabía que lo que se decidiera le iba a afectar personalmente a él y a su familia. Para mantener el orden en la Ekklesia había unas fuerzas de seguridad que curiosamente eran esclavos y estaban a las órdenes de los pritanos que presidían las sesiones, generalmente su intervención no era necesaria porque la cortesía y el respeto eran la tónica general. 
Los atenienses no creían que la palabra dañase la acción, al contrario, sentían la necesidad de ilustrarse antes de actuar (TUCÍDIDES); la política ya no era materia de la religión, era necesario meditar y reflexionar las razones por las que se tomaba una decisión y no otra, hasta encontrar la más favorable a los intereses generales. La libertad de todos los ciudadanos en el uso de la palabra garantizaba la resolución de los múltiples problemas y asuntos públicos de la manea más beneficiosa para todos.

El estado de salud de la democracia directa ateniense se mide por el grado de participación de los ciudadanos en la vida política, porque de ello depende la mayor o menor legitimidad de las decisiones adoptabas por el pueblo soberano. Durante el siglo V a.C., como no se había establecido una remuneración por asistir a la Ekklesia, frecuentemente sólo asistían una o dos quintas partes de los ciudadanos ${ }^{79}$. Este hecho es entendible teniendo en cuenta; por una parte, que la gran mayoría de la población eran jornaleros, artesanos, pequeños propietarios de predios, por lo que acudir les suponía la pérdida de una jornada de trabajo, y por otra, la distancia que les separaba con la ciudad dificultaba aún más la presencia de muchos ciudadanos.

Al terminar la Guerra del Peloponeso (403 a.C.), se empieza a retribuir la asistencia ${ }^{80}$ (misthos $^{81}$, provocando una gran afluencia de los pobres a las sesiones de la Asamblea, de modo que las decisiones políticas recogen el sentir no sólo de un mayor número de ciudadanos, sino de este estrato social, por lo que la democracia se vio refortalecida con esta medida.

A las ya referidas competencias legislativas y en materia de relaciones internacionales, hay que destacar la facultad de elegir a los ciudadanos que van a desempeñan ciertas magistraturas, que por su trascendencia para Atenas debían ser ocupadas por ciudadanos en los que concurrieran unas especiales cualidades que les permitieran realizar de manera eficiente estas importantes funciones para la polis. La magistratura de strategos fue la única que podía ser ejercida por la misma persona durante más de un año, como fue el caso de Pericles,

${ }^{79}$ OBER, J., Mass and Elite in Democratic Athens, Princeton University Press, 1989, p. 132.

${ }^{80}$ ARISTÓTELES, Constitución de los Atenienses, 41.

${ }^{81}$ El misthos era de dos óbolos y posteriormente sería de tres, sin embargo, cada sesión de la Ekklesia tenía un presupuesto, de modo que cuando se agotaba ya no se podía retribuir a los demás que habían asistido pero que había llegado más tarde. (ALMANDÓS, L., op. cit., p. 179). 
sin embargo, estaba sometida a un régimen de control más exhaustivo que el resto debido a su naturaleza militar; al inicio de cada pritanía los diez strategos debían someterse a una votación de confianza de su gestión, en caso de no obtenerla eran juzgados, pero si no eran sancionados recuperaban el cargo, ${ }^{82}$ asimismo, estos magistrados estaban sometidos al control de su gestión por parte de todos los ciudadanos al término del ejercicio de su magistratura.

\section{III.1.C. Los Dikasterios}

Al entregar Solón la justicia al pueblo, permitió que cualquier ciudadano pudiera ejercer este poder soberano, y sin duda estableció los cimientos para el progresivo establecimiento del régimen democrático ateniense.

Durante el período de tiempo en el que estuvo vigente la democracia participativa en Atenas, la potestad jurisdiccional en causas civiles y penales se canalizó a través de una pluralidad de cargos públicos y órganos judiciales colegiados, cuyos miembros eran elegidos por sorteo para un período anual entre todos los ciudadanos:

- Los diez instructores de causas tenían encomendada la función de juzgar aquellos pleitos urgentes, debían resolverse en el término de un mes, fundamentalmente en materia civil. ${ }^{83}$

- Los Cuarenta, cuatro por tribu, cuya competencia recaía sobre pleitos civiles de hasta diez dracmas, si la cuantía era superior el asunto era competencia de los arbitradores. ${ }^{84}$

- Los arbitradores tenían la misión de conseguir una transacción judicial entre las partes para poner fin al conflicto mediante un acuerdo extrajudicial que se documentaba en un laudo, en caso de que no fuera posible conciliar las posturas enfrentadas, se remitía el litigio al dikasterio correspondiente para que procediera a su enjuiciamiento. Este cargo era obligatorio para todos aquellos ciudadanos mayores de sesenta años a los que se les asigna un número de asuntos que debían resolver necesariamente y en caso de incumplimiento eran sancionados. ${ }^{85}$

\footnotetext{
${ }^{82}$ ARISTÓTELES, Constitución de los atenienses, 61-2.

${ }^{83}$ Ibidem, $52-2$ y 3.

${ }^{84}$ Ibidem, 53-1 y 2.

${ }^{85}$ Ibidem, 53-2 y 4. Cfr. DEMÓSTENES, Discursos, "Contra Áfobo», 1, XVII 1.
} 
- El Consejo del Areópago y el Tribunal de Efetas continuaron ejerciendo sus tradicionales competencias penales sobre el enjuiciamiento de los delitos de sangre. Los tribunales (dikasterios) estaban formados por un presidente (arconte) que establecía el orden de los juicios y por aquellos ciudadanos mayores de treinta años, en el pleno ejercicio de sus derechos civiles y sin deudas pendientes con la ciudad-estado, ${ }^{86}$ (dikastai) que salían elegidos mediante sorteo, debiendo solicitar previamente su inclusión en el mismo; ejercían las funciones de jueces y jurado ${ }^{87}$. Anualmente se designaban seis mil jueces, seiscientos de cada tribu, para atender a las necesidades de la justicia ateniense, y se incorporaban a alguno de los numerosos dikasterios, formados por un número diferente de miembros dependiendo de la causa que tuvieran que enjuiciar: en los litigios civiles de hasta mil dracmas, estaba compuesto de 201 miembros y en los de más de mil por 401 ciudadanos $^{88}$, en las causas penales, estaba formado por 500, 1000 o para las más graves 1500 miembros. ${ }^{89} \mathrm{El}$ tribunal más conocido era el del Heliaia que se encontraba en el ágora, pero había más dikasterios repartidos por toda la ciudad; se celebraban los jui$\operatorname{cios}^{90}$ durante todos los días laborables, excepto los tres últimos días de cada mes y los días en que la Ekklesia tenía en sesión.

En el año 416 a.C., se aprobó el graphe paranomon (contrario a las leyes), el precedente más antiguo del recurso de inconstitucionalidad. Era una ley que encomendaba a la los dikasterios la misión de proteger la democracia.C.ada ciudadano era responsable no sólo de las leyes que presentaba, sino también de las que una vez propuestas eran

\footnotetext{
${ }^{86}$ Ibidem, 63-3.

${ }^{87}$ ARISTÓTELES describe de forma muy prolija el complejo procedimiento por el que se determinaba qué dikastai integraban los diferentes tribunales, con el fin de garantizar su imparcialidad y el desarrollo de los juicios. Por otra parte, la voluntad del dikasterio se formaba por votación, cada juez introducía su voto en una urna de bronce y era en ese momento en el que recibía el estipendio por ejercer su cargo para que así obligatoriamente todos votaran. Una vez finalizados los sufragios, se producía el recuento de votos a favor del actor y del demandado o acusado, ganaba el pleito el que obtuviera más votos y en caso de empate el demandado. En el caso de que fuera una causa penal, se volvía a realizar una votación para la determinación de la pena que había que aplicar al condenado. (Cfr. Ibidem 64-68).

${ }^{88}$ Ibidem, 53-3.

${ }^{89}$ Ibidem, 68-1.

${ }^{90}$ Sobre la liturgia religiosa que rodeaba a los juicios, cfr. ARISTOFANES, Avipas, 830 y $860-865$.
} 
aprobadas por la Asamblea, en el caso de que dañaran los intereses de Atenas o fueran en beneficio propio, porque cualquier ciudadano podía denunciar la proposición o la ley, suspendiéndose ipso iure su tramitación o aplicación hasta que el tribunal dictaminase si era cierta o no la acusación. En caso afirmativo, al que había presentado la proposición y, cuando el objeto de impugnación era una ley vigente también al presidente de la Asamblea, se les imponían graves sanciones pudiendo llegar a la atimia ${ }^{91}$, de igual manera que el denunciante debía responder si la acusación era rechazada.

\section{CONCLUSIONES}

Las diferencias entre la democracia ateniense y las actuales son importantes, mientras que aquélla era directa, sin partidos políticos y con una incipiente división de poderes, las nuestras son representativas, con una consolidada institucionalización de la separación de poderes y los partidos políticos se han convertido, en la práctica, en el único cauce para la participación en la vida política. Sin embargo, ambas perseguían estabilidad política, justicia, igualdad legal, atenuar las profundas diferencias sociales y económicas y la libertad, pero su concepción de ésta era radicalmente diferente a la nuestra y es la clave de bóveda del sistema, la que determina los caracteres del régimen político ateniense de los siglos V y IV a.C.

Siguiendo a CONSTANT ${ }^{92}$, los antiguos entendían la libertad como libertad política, como participación directa en el poder social, en la toma de decisiones sobre los asuntos públicos; sentían que eran soberanos, que su voto tenía influencia decisiva en el destino económico, político y social de la ciudad. Sin embargo, despreciaban su libertad individual porque aceptaban y permitían que la autoridad del cuerpo político se extendiera sobre aquellas cuestiones relativas al ámbito privado de los ciudadanos, todas las esferas de su vida personal estaban férreamente reguladas, nada se dejaba a su libre voluntad.

En la actualidad, se le otorga un valor preponderante a la libertad individual sobre la política; los ciudadanos consideran imprescindible

${ }^{91}$ La atimia era una pena que imponían los tribunales, cuyo objeto era la privación de la ciudadanía, de manera que el condenado estaba inhabilitado para ejercer los poderes soberanos. El átimos era aquella persona a la que le estaba prohibida la asistencia a la Ekklesia, ejercer como dikastai, interponer acciones judiciales ante los tribunales y ser miembro de la Boulé.

${ }^{92}$ Op. cit., pp. 257-285. 
reservar y proteger su independencia privada frente a la injerencia y el control de los poderes públicos. No encontramos satisfacción en el ejercicio de los derechos políticos, ya que no percibimos que tengamos influencia directa en la formación de la voluntad general del cuerpo soberano. Nos consideramos más libres cuanto más tiempo tenemos para dedicarnos a nuestros asuntos privados, por eso delegamos la gestión de la res publica en unos representantes, empero, corremos el peligro de que al centrarnos exclusivamente en nuestros intereses particulares obviemos nuestro derecho de participación política y esto provoque que los depositarios de los poderes constituidos se comporten como si fueran el soberano.

La partitocracia no sólo ha sustraído de facto los poderes soberanos al pueblo, sino que se ha empleado con una notable diligencia en neutralizar, por la vía del desarrollo legislativo, todos los instrumentos jurídico-participativos, previstos en la Constitución española, dirigidos a incentivar, promover y favorecer la intervención directa de los ciudadanos en la vida política, como complemento idóneo al sistema representativo. Por ello, con el fin de revitalizar y potenciar la preocupación, participación y toma de posición de los ciudadanos en las cuestiones públicas sería interesante analizar con detenimiento, en posteriores investigaciones, algunas instituciones atenienses, que podrían ser importables, mutatis mutandi, a nuestro ordenamiento jurídico.

La dokimasía se traduciría en nuestra legislación como la obligación, al término de la magistratura, de rendir cuentas ante la respectiva Comisión parlamentaria por todos aquellos altos cargos del Gobierno, y la posibilidad de que cualquier ciudadano pudiera presentar quejas a su gestión, deduciéndose las correspondientes responsabilidades en que, en su caso, hubieran incurrido. En la actualidad, este instrumento de control, junto con otros como la remoción y la revocación de autoridades, están previstos en las legislaciones de los países latinoamericanos y permiten una mayor implicación de la ciudadanía en los asuntos públicos e inciden positivamente en una mejora de la gestión por parte los burócratas.

En cuanto a la iniciativa legislativa, en Atenas cualquier ciudadano estaba legitimado para presentar una proposición de ley ante la Boulé, bien es cierto que actualmente esto sería inviable por razones prácticas. Sin embargo, es evidente que la iniciativa legislativa popular es una cuestión mal resuelta en nuestro ordenamiento jurídico, porque es un mecanismo típicamente participativo, desdibujado de tal manera por nuestra Constitución y por el legislador orgánico, 
que se ha convertido en un instrumento inservible e inútil para potenciar la participación directa de los ciudadanos, por lo que es imprescindible una reforma profunda de la misma.

De la institución del graphe paranomon, la extensión de la legitimación activa para la interposición del recurso de inconstitucionalidad a cualquier ciudadano que acredite la condición de interesado, y de recuperar el recurso previo de inconstitucionalidad para determinadas materias especialmente sensibles.

Por otra parte, es necesario valorar, en términos democráticos, el concepto de ciudadanía vigente en la ciudad, ya que era el título jurídico que legitimaba para participar en la vida política.

Se privó de la ciudadanía a los esclavos, extranjeros y a las mujeres, lo que podría llevarnos, prima facie, a la precipitada conclusión de que en realidad no estamos ante el gobierno del pueblo, por el importante déficit democrático que presenta Atenas al estar discriminada una parte considerable de la población, a la que se le cercenaron todos sus derechos políticos. Sin embargo, hay que tener en cuenta que las mujeres han sido discriminadas hasta fechas recientes en todos los órdenes y, circunscribiéndonos al ámbito político, observamos que en España se les reconoció por primera vez el derecho de voto en la Constitución de la II República, en los Estados Unidos, hasta el año 1920 no se aprobó la enmienda XIX de la Constitución que prohibió la discriminación por razón de sexo en el derecho al sufragio, y en Inglaterra hasta 1928.

Por otra parte, el estatus jurídico que Atenas dio a sus esclavos fue el mismo que España impuso a los suyos, hasta que la esclavitud fue abolida en 1886 cuando el Ministro de Ultramar Germán Gamazo suprimió la institución del Patronato de los ex-esclavos de Cuba, e idéntico al que les confirieron los Estados Unidos hasta que el presidente Lincoln promulgó la Declaración de Emancipación en 1863, pero que no entraría en vigor hasta que terminara la Guerra de Secesión en 1865, y en Francia hasta 1848.

Actualmente, en nuestro propio país, el derecho de sufragio para los extranjeros está muy restringido porque sólo está previsto para las elecciones locales y sobre la base del principio de reciprocidad.

Por tanto, el balance de la democracia ateniense es satisfactorio porque los aspectos positivos: haber conseguido el mayor grado de participación de los ciudadanos en la vida política que jamás en la historia de la humanidad se ha vuelto a repetir, donde cada ciudadano podía ejercer directamente, sin representantes, los poderes sobe- 
ranos, primaron sobre los negativos que no son tan intensos, si los analizamos con la perspectiva histórica del momento en el que se desarrolló la democracia ateniense y teniendo en cuenta que ha costado más de veinte siglos poner fin a alguna de esas discriminaciones, de lo cual nos alegramos enormemente, mientras que otras aún persisten. 